\title{
Bio-efficacy of Clerodendrum capitatum (Willd) Schumachet. Thonn. (Lamiales: Verbenaceae) against Dermestes maculatus De Geer, 1774 (Coleoptera: Dermestidae) larvae infestation on smoked catfish Claria gariepinus (Burchell, 1822) (Siluriformes: Clariidae)
}

\section{Jacobs Mobolade Adesina ${ }^{13}$, Adeolu Rufus Jose $^{2}$ and Yallappa Rajashekar $^{3}$}

${ }^{1}$ Department of Crop, Soil and Pest Management Technology, Rufus Giwa Polytechnic, P. M. B. 1019, Owo, Ondo State, Nigeria. Email: moboladesina@yahoo.com.

${ }^{2}$ Department of Science Laboratory Technology, Rufus Giwa Polytechnic, P. M. B. 1019, Owo, Ondo State, Nigeria.

${ }^{3}$ Chemical Ecology Laboratory, Institute of Bioresources and Sustainable Development, Department of Biotechnology, Govt. of India, Takyelpat, Imphal-795001, Manipur, India.

\begin{abstract}
Studies were conducted under ambient condition to assess the efficacy of Clerodendrum capitatum (Willd) Schumachet. Thonn. (Lamiales: Verbenaceae) against larvae infestation and adult emergence of Dermestes maculatus De Geer, 1774 (Coleoptera: Dermestidae) on smoked dried catfish Claria gariepinus (Burchell, 1822) (Siluriformes: Clariidae). The leaf powder was admixed at $2.5 \mathrm{~g}, 3.0 \mathrm{~g}, 4.0 \mathrm{~g}$ and $5.0 \mathrm{~g} / 15 \mathrm{~g}$ to disinfected smoke-dried catfish Clarias gariepinus separately in a $125 \mathrm{~mL}$ plastic container. Ten newly emerged (0-72 h) larvae of $D$. maculatus were introduced into each of the plastic containers. Efficacy of Clerodendrum capitatum was assessed based on percentage larval mortality, adult emergence reduction and weight loss. Results showed that the plant powder cause significantly $(p<0.05)$ larval mortality compared to the untreated fish at $24 \mathrm{~h}, 48 \mathrm{~h}$ and $72 \mathrm{~h}$ post infestation. Percentage reduction of adult emergence was not significant $(p>0.05)$ in treated fish samples compared to untreated sample. While fish sample protected with powder of Clerodendrum capitatum, exhibit significant $(\mathrm{p}<0.05)$ low weight loss as against weight loss observed in untreated fish. The efficacy of Clerodendrum capitatum is inversely proportional to increase in dosage rate. This study clearly demonstrated the larvicidal potential of Clerodendrum capitatum powder in offering effective protection against infestation and damage by $D$. maculatus and recommended for utilization in integrated post-harvest management strategies of smoke-dried fish.
\end{abstract}

Keywords: Claria gariepinus; Clerodendrum capitatum; Dermestes maculatus; Infestation; Smoke-dried fish; Integrated post-harvest management; African sharptooth catfish.
Received

December 29, 2015

Accepted

April 2, 2016

Released

June 30, 2016

Open Acess

Full Text Article

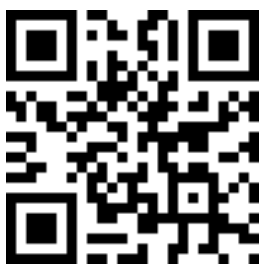

ORCIT

(๖) 0000-0003-1174-9095

Jacobs Mobolade

Adesina

(ㄱ) 0000-0001-6512-6294

Adeolu Rufus Jose

(ㄱ) 0000-0001-6707-4643

Yallappa Rajashekar 


\section{Introduction}

Smoked or dried fish is a highly favored item of many traditional dishes in Nigeria and it is a condiment that greatly enriches the flavor of various dishes and a good alternative to fresh fish, which in many places is not readily available (Obiakor et al., 2013). Adesina et al. (2014) reported that fish constitutes about $50 \%$ of total animal protein intake in Nigeria as the cost of beef increases daily and owing to its nutritional and health benefit; this account for its wide acceptability on the menu table of most Nigerians irrespective of socioeconomic status, age and religious background. According to Clement (2013), $45 \%$ of total fish catch in Nigeria are utilized as smoked fish. However, research has proved that most of the smoked fish that are carried to long distant markets from fishing areas are susceptible to Dermestes maculatus De Geer, 1774 infestation (Idris and Omojowo, 2013). Under traditional storage conditions, losses due to beetle infestation for instance, have been estimated at 50\% (Nayak et al. 2014; Rajashekar et al., 2014). Larval stages of $D$. maculatus usually accounts for 93\% infestation in dried or smoked fish. Losses caused by $D$. maculatus infestation are enormous. They include physical, economic and nutritional loss and their infestation also predisposes the infested fish to microbial attack (Woo, 1992; Brock and Bullis, 2001).

Although many synthetic chemicals are effective against the pests of many stored products, but efforts to reduce losses through insect infestation on smoke-dried fish by the use of insecticides and pesticides have not been fully adopted due to the hazardous nature of these chemicals to health and toxicity at high doses to users (Balogun, 1992); higher costs and less susceptibility of dermestid larvae (Amusan and Okorie, 2002), the use of such insecticides renders smoked fish unattractive to fish consumers (Akinwumi et al., 2007). In order to eliminate much of the shortcomings associated with the use of synthetic insecticides and provide an effective storage techniques; in recent year, there have been increasing and concerted effort at developing plant based toxicants that are environmentally friendly. It was reported that when dried or smoked fish was mixed with leaf, bark, seed powder, or oil extracts of selected plants, there was mortality of beetles, reduced oviposition rate, suppression of adult emergence and reduced fish damage rate (Don-Pedro, 1985, 1989; Weaver and Subramanyam, 2000; Okonkwo and Okoye, 2001; Anyaele and Amusan, 2003a,b). Clerodendrum capitatum (Willd) Schumachet. Thonn. var capitatum (Family Verbenaceae), locally named "Fèrèmomi" in Yoruba, is an indigenous Tropical Africa fast growing, erect, well branched, perennial under shrub which grows up to 0.5-2 m high (Adeneye et al., 2008). The plant popularly called as medicinal-magical plant for bone healing in fractures (Houngnon et al., 1990), it is equally reputed for local management of diabetes mellitus, obesity and hypertension. Recently, Juvekar et al. (2006) reported immune stimulatory activity of aqueous extract of Clerodendrum serratum L. roots in mice. Sharma and Bhuyan (2006) equally reported the hypolipidemic activities of glycosides isolated from Clerodendrum colebrookianum Walp leaves in mice. However, there are no reports on insecticidal activity of Clerodendrum capitatum against coleopteran pests. Therefore, the present study aims to investigate the efficacy of Clerodendrum capitatum leaves powder in suppressing infestation and damage caused by $D$. maculatus larvae on smoked catfish Claria gariepinus (Burchell, 1822).

\section{Materials and methods}

\section{Insect culture and maintenance}

The initial source of $D$. maculatus culture used for this study was obtained from natural infested smoked catfish (Clarias gariepinus) collected from smoked fish market stall in Owo, Ondo State, Nigeria. This was maintained in a kilner jar covered with muslin cloth under laboratory 
conditions of temperature $30 \pm 2{ }^{\circ} \mathrm{C}$ under relative humidity $65 \pm 5 \%$ to breed and multiply. New generations was produced by removing newly emerged larvae from a stock culture, placed them on fresh uninfected fish, and then the parent adult removed after 2-3 weeks oviposition period.

Smoked samples of the fish (Clarias gariepinus) were purchased from the fish market stall at Oja Oba Market, Owo, Ondo State, Nigeria. The cured fish samples were sterilized in a hot air oven at $100{ }^{\circ} \mathrm{C}$ in order to kill any insect pests that may be present (Atijegbe, 2004), and allowed to cool at room temperature.

\section{Preparation of Clerodendrum capitatum leaves powder \\ Whole plant of Clarias capitatum} was collected from Ilutitun Community in Okitipupa of Ondo State, Nigeria, and the identity of the plant was confirmed at the Forestry and Wood Technology Department, Rufus Giwa Polytechnic, Owo, Ondo State, Nigeria. The plant material was washed in clean water to remove any dirt material and shade dried for two weeks, and leaves plucked and pulverized using an electric grinder and sieved. The plant powder was kept in a separate sterile plastic container and placed in a cool dry place till further use.

Effect of Clerodendrum capitatum leaves powder on larvae and adult emergence of $D$. maculatus

Twenty grams (20 g) of clean uninfested fish sample was weighed into $250 \mathrm{~mL}$ plastic vials. To each vials various dosages (2.5 g, $3.0 \mathrm{~g}, 4.0 \mathrm{~g}$ and $5.0 \mathrm{~g}$ ) of plant powder was added. Another set of fish samples without plant powder was served as control. Ten newly emerged larvae of D. maculatus was introduced into each treated and control vials containing fish samples and covered. The content of the vials was thoroughly mixed to ensure the coating of the powder on fish samples. Each treatment was replicated three times and arranged in Completely Randomized Design (CRD). The number of dead larvae was counted after $24 \mathrm{~h}, 48 \mathrm{~h}$ and $72 \mathrm{~h}$ to determine larvae mortality.

Insect subsequently emerging was counted to estimate percentage reduction in adult emergence of F1 progeny using method described by Tapondju et al. (2002) and modified by Adesina et al. (2014).

Weight loss was determined by reweighing the fish samples at the end of the experiment.

Percentage larvae mortality $=$

\title{
$\frac{\text { no of live larvae before treatment }- \text { no of live larvae after treatment }}{\text { no of larvae before treatment }} \times \frac{100}{1}$
}

Percentage adult emergence reduction:

\author{
$=\frac{\text { no of adult insect emerged in control dish }- \text { no of adult insect emerged in treated dish }}{\text { no of adult insect emerged in control dish }} \times \frac{100}{1}$ \\ \% Weight loss (Adesina et al., 2014) = \\ $\frac{\text { initial weight of fish sample - final weight of fish sample }}{\text { initial weight of fish sample }} \times \frac{100}{1}$
}

Braz. J. Biol. Sci., 2016, v. 3, no. 5, p. 37-44. 


\section{Statistical analysis}

All data obtained was subjected to analysis of variance and where significant differences existed, treatment means was separated using Least Significant Difference (LSD) at 5\% probability level. Data in percentage were arcsine transformed, before analysis (Gomez and Gomez, 1984).

\section{Results and discussion}

\section{Effect of Clarias capitatum on larvae mortality}

Percentage larvae mortality of $D$. maculatus was summarized in Figure 1. The results revealed that pulverized Clarias capitatum leaves powder exerted significant $(\mathrm{p}<0.05)$ larvae mortality in all the treated dishes compared to control. The percentage mortality of $D$. maculatus larvae depends on the concentration level and exposure time. For the entire dosage rate used, percentage larvae mortality increased as exposure time increases. At $72 \mathrm{~h}$ post infestation larvae exposed to $5 \mathrm{~g}$ plant powder had the highest larvae mortality (37.2\%), lowest mortality recorded from fish protected with $2.5 \mathrm{~g}$ powder (17.2\%). No mortality was observed in control treatment (Figure 1). However, 100\% mortality was not achieved in any of the treatment rates.

The mortality caused by the powder might be due to its tendency to block the spiracles of insects when in contact with their body. Most insects breathe through the trachea which usually leads to the opening of the spiracles (Kemabonta and Falodu, 2013). The powder may cause death through dessication of insects or through occlusion of their spiracles, thereby preventing respiration via tracheal system (Copping and Menn, 2000). This supports the findings of other researchers who had earlier reported on the efficacy of larvicidal activities of various plant products as surface protectant against D. maculatus infestation (Fasakin and Aberejo, 2002; Adebote et al., 2006; Akinwumi et al., 2007).

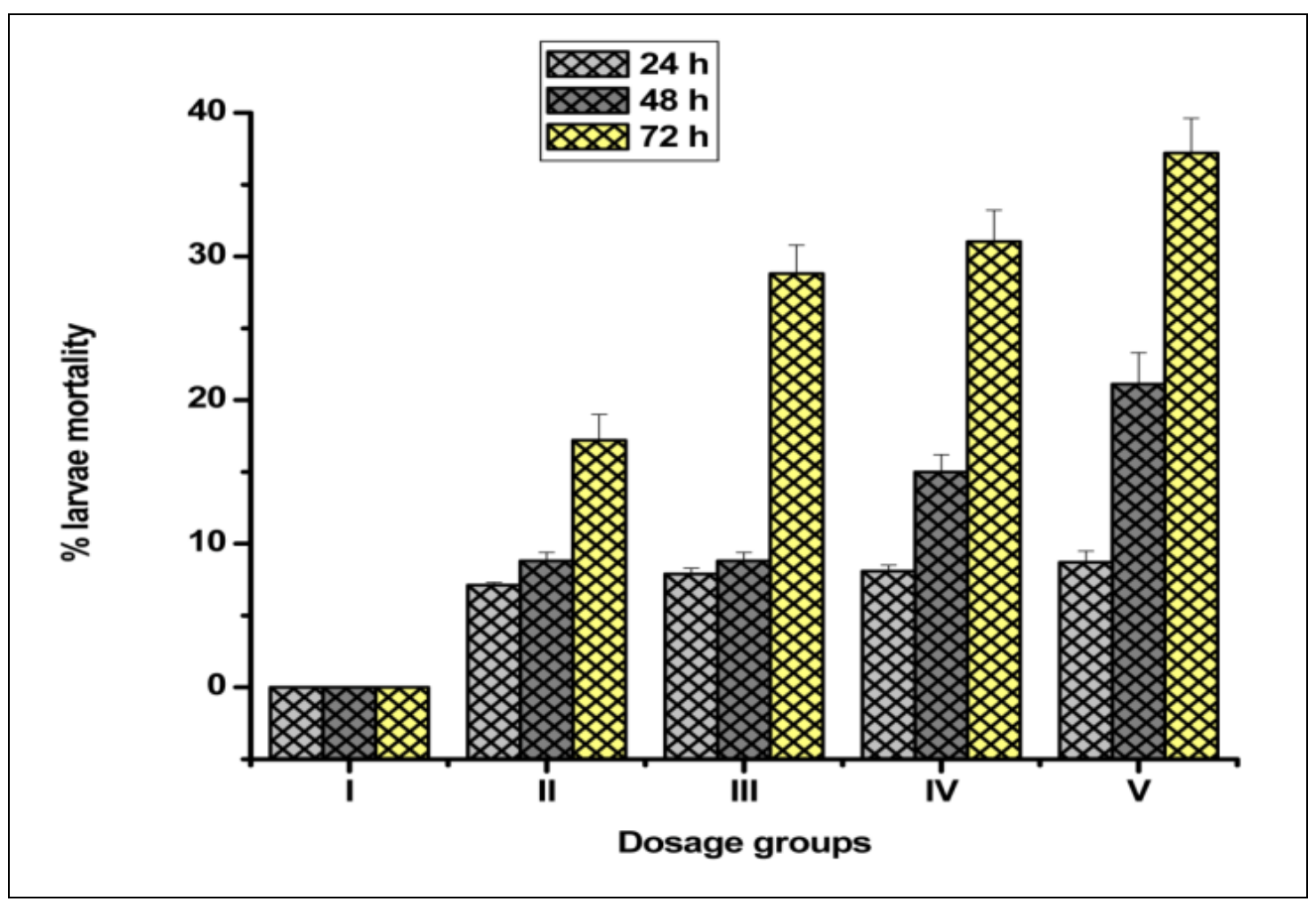

Figure 1. The effect of Clerodendrum capitatum on percentage larvae mortality of $D$. maculates. $\mathbf{I}=0 \mathrm{~g}$; II = $2.5 \mathrm{~g} ; \mathbf{I I I}=3.0 \mathrm{~g} ; \mathbf{I V}=4.0 \mathrm{~g} ; \mathbf{I V}=5.0 \mathrm{~g}(\mathrm{n}=4$, error bars, SEM $)$. 


\section{Effect of Clerodendrum capitatum on percentage adult emergence reduction \\ Figure 2 shows the effect of} Clerodendrum capitatum powder on percentage adult emergence reduction. Result obtained from the study clearly shows that unprotected fish samples had the lowest adult emergence reduction percentage compared to treated samples that recorded varying promising percentage adult emergence reduction ranging $28.8 \%$ $26.7 \%$ and with the highest emergence reduction percentage obtained from fish admixed with $5 \mathrm{~g}$ plant powder (26.7\%). However, the plant powder suppressed adult emergence, but the observed differences were not statistically significant between the treatments.

The significant reduction in the adult emergence could be as a result of higher mortality of $D$. maculatus larva. The reduction in adult emergence can also be attributed to the contact effect of the plant material, similar observations were made by (Kedia et al., 2015). Further, this is in agreement with the findings of Don Pedro (1985) who reported that orange peel powder reduced progeny development and slowed larval development of $D$. maculatus.

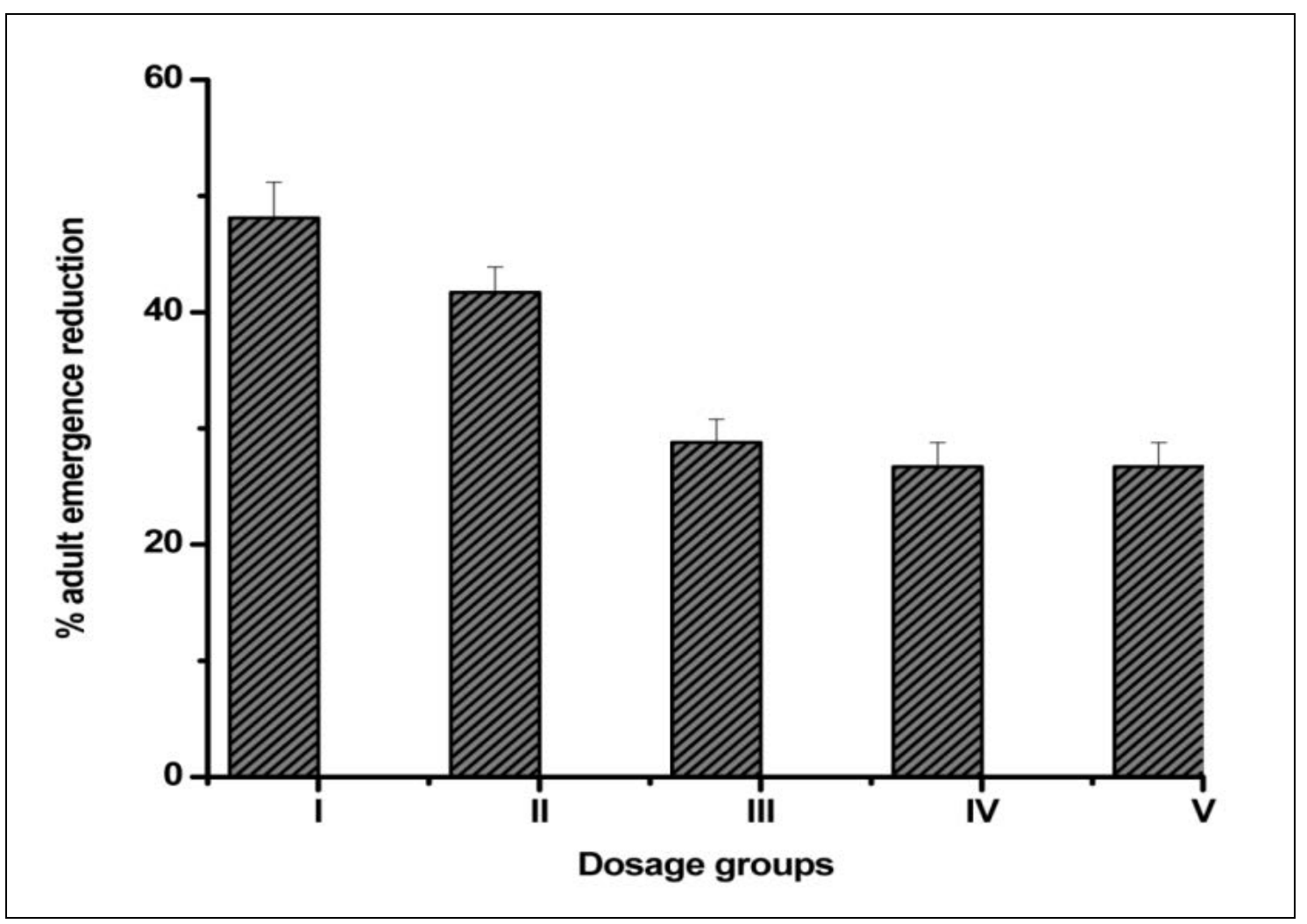

Figure 2. The effect of Clerodendrum capitatum on percentage adult emergence reduction of D. maculates. I = 0 g; II = $2.5 \mathrm{~g}$; III = $3.0 \mathrm{~g} ; \mathbf{I V}=4.0 \mathrm{~g} ; \mathbf{I V}=5.0 \mathrm{~g}(\mathrm{n}=4$, error bars, SEM $)$.

\section{Effect of Clerodendrum capitatum on percentage weight loss of protected fish samples}

Percentage weight loss obtained from the result shows that unprotected fish suffer significant $(\mathrm{p}<0.05)$ weight loss (35.07\%) compared to fish protected with Clarias capitatum leaves powder with the lowest weight loss $(23.77 \%)$ recorded from fish treated with $5 \mathrm{~g}$ powder (Figure 3).
This could be attributed to larvae mortality recorded and this is in accordance with the findings of Jose and Adesina (2014) who reported that pulverized Secamone afzelii (Schult) K. Schum leaves significantly suppressed weight loss in smoked dried fish. Osuji (1975) stated that the larval stages of $D$. maculatus usually account for about $93.2 \%$ of the beetles and account for $62.7 \%$ weight loss due to its infestation. 
The larvae especially at the 1st-4th instar larval stage are voracious eaters because of growth requirements, in contrast to the adult insects which tend to have a reduced feeding habit.

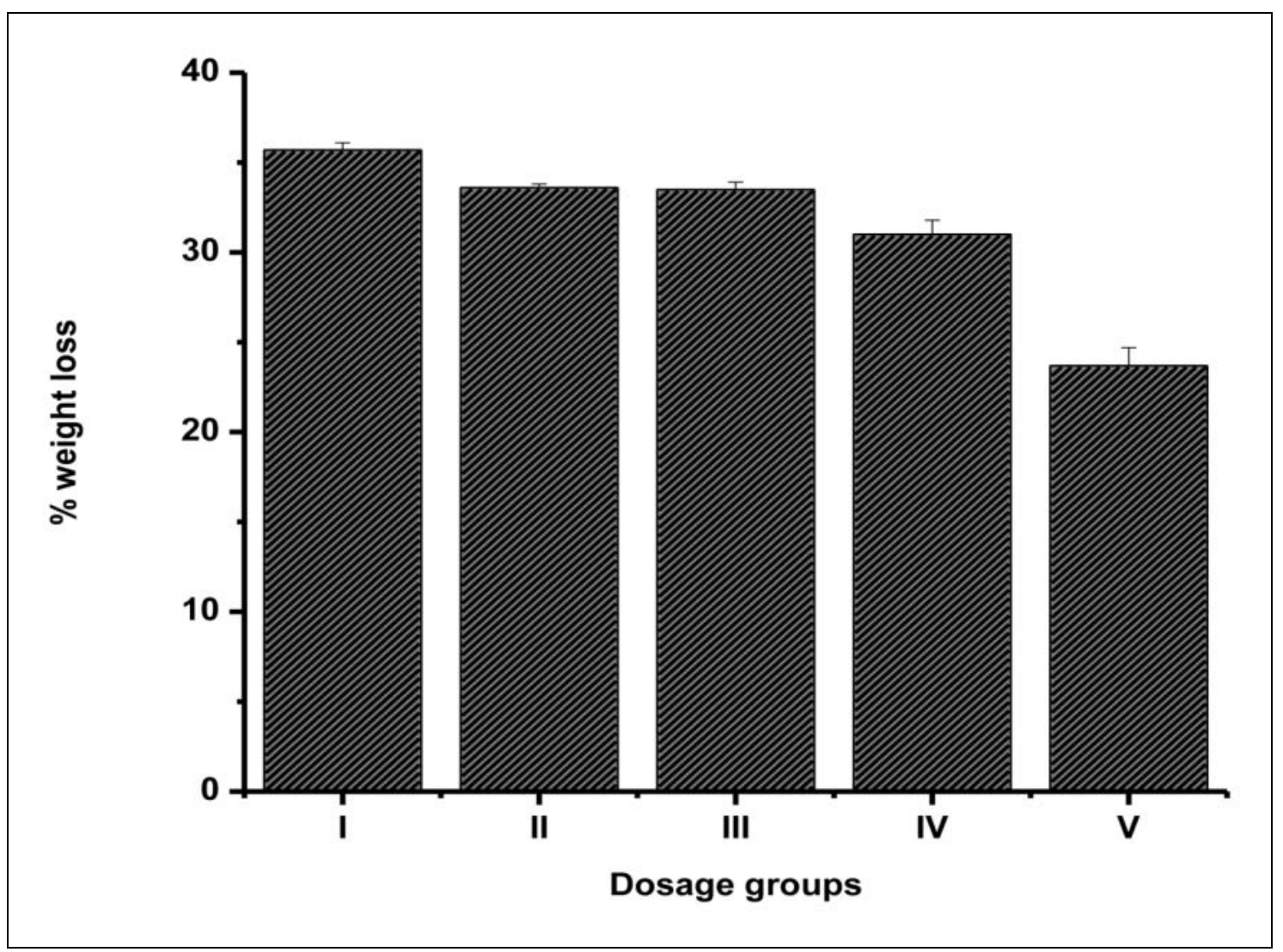

Figure 3. The effect of Clerodendrum capitatum on percentage weight loss of fish samples. $\mathbf{I}=0 \mathrm{~g}$; $\mathbf{I I}=2.5 \mathrm{~g} ; \mathbf{I I I}=3.0 \mathrm{~g} ; \mathbf{I V}=4.0 \mathrm{~g} ; \mathbf{I V}=5.0 \mathrm{~g}(\mathrm{n}=4$, error bars, SEM $)$.

\section{Conclusion}

The results obtained in this study showed that leaf powder of Clerodendrum capitatum was toxic to the fish bettle, $D$. maculatus, causing significant larvae mortality and suppressed adult emergence. The weight loss is also significant when compared to the control treatments. The use of Clerodendrum capitatum among poor resource fisher farmers and traders should be advocated for the control of $D$. maculatus infestation during processing, storage, transportation and marketing of smoked dried fish, since the plant is readily available and widely distributed in the rural area of rain forest zone in Nigeria and used among rural folks for its ethno medical importance. Further study needs to be conducted to understand the mode of action of the plant toxicity effects and also the characterization and isolation of the chemical constituents needs to be conducted with the likely formulation into herbal insecticide as alternative to synthetic insecticides.

\section{Acknowledgement}

The authors wish to thank the Director, Institute of Bioresources and Sustainable Development, Imphal, Manipur, India and Miss Omogazi, Titilayo Elizabeth, Department of Science Laboratory Technology, Rufus Giwa Polytechnic, Owo, Ondo State, Nigeria for his keen interest in this study and in collecting all necessary data needed for the study respectively. The First author acknowledges the financial support by the 
Department of Science and Technology (DST), New Delhi, India, through CV Raman Fellowship for African Researchers.

\section{Conflict of interest statement}

Authors declare that they have no conflict of interests.

\section{References}

Adebote, D. A.; Abolude, D. S.; Oniye, S. J.; Olododo, S. S.; Hassan, M. M. Larvicidal and repellent actions of Detarium microcarpum seed oil against the larvae of Dermestes lardarius (Coleoptera: Dermestidae) in dried Clarias gariepinus fish. Journal of Entomology, v. 3, n. 3, p. 248-253, 2006.

Adeneye, A. A.; Adeleke, T. I.; Adeneye A. K. Hypoglycemic and hypolipidemic effects of the aqueous fresh leaves extract of Clerodendrum capitatum in Wistar rats. Journal of Ethanopharmacology, v. 116, p. 7-10, 2008.

Adesina, J. M.; Jose, A. R.; Adetuyi, O. O.; Olorunfemi, D. A. Larvicidal activity of Phyllanthus fraternus powder in suppressing Dermestes maculatus Degeer (Coleoptera: Dermestidae) infestation on smoked African catfish (Clarias gariepinus), International Journal of Aquaculture, v. 4, n. 11, p. 67-72, 2014.

Akinwumi, F. O.; Fasakin, E. A.; Adedire, C. O. Toxic and repellency activities of four plants extract to Dermestes maculatus (Degeer) on smoked African mud catfish, Clarias gariepinus Burchell. Journal of Entomology, v. 4, n. 2, p. 149-154, 2007.

Amusan, A. A. S.; Okorie, T. G. The use of Piper guineese fruit oil (PFO) as protected of dried fish against Demestes maculatus (Degeer) infestation. Global Journal of Pure an Applied Science, v. 8, p. 197-201, 2002.

Anyaele, O. O.; Amusan, A. A. S. Toxicity of hexanolic extract of Dennettia tripetala, Piper guineense Schum and Thonn against Dermestes maculatus Degeer (Coleoptera: Dermestidae) and Necrobia rufipes Degeer (Coleoptera: Cleridae) on dried fish. Nigeria Journal of Entomology, v. 18, p. 109-117, 2003a.

Anyaele, O. O.; Amusan, A. A. S. Toxicity of hexanolic extracts of Dennettia tripetala (G. Baker) on toxicity of Aedes aegypti (L). African Journal of Biomedical Research, v. 6, n. 1, p. 49-53, 2003b.
Atijegbe, S. R. Infestation of smoked fish in Ghana. Accra: University of Ghana, 2004. (Thesis).

Balogun, A. M. Fish handling and quality control. In: Cowx, I. G. (Ed.). Aquaculture development in Africa: training and references manual for aquaculture extensionists. London: Commonwealth Secretariat, 1992. p. 290-318.

Brock, J. A.; Bullis, R. Disease prevention and control for gametes and embryos of fish and marine shrimp. Aquaculture, v. 197, n. 1-4, p. 137-159, 2001.

Clement, A. R. Vulnerability of fisheries livelihood in the coastal area of Niger Delta Region of Nigeria. World Journal of Fish Marine Science, v. 5, n. 2, p. 152-158, 2013.

Copping, L. G.; Menn, J. J. Biopesticides: a review of their action, applications and efficacy. Pest Management Science, v. 56, n. 8, p. 651676, 2000.

Don-Pedro, K. N. Toxicity of some citrus peels to Dermestes maculatus Deeger and Callosobruchus maculatus (F). Journal of Stored Products Research, v. 21, n. 1, p. 3134, 1985.

Don-Pedro, K. N. Insecticidal activity of some vegetable oils against Dermestes maculatus Degeer (Coleoptera: Dermestidae) on dried fish. Journal of Stored Product Research, v. 25, n. 2, p. 81-86, 1989.

Fasakin, E. A.; Aberejo, B. A. Effect of some pulverized plant materials on the developmental stages of fish beetle, Dermestes maculatus Degeer in smoked catfish (Clarias gariepinus) during storage. Bioresouces Technology, v. 85, n. 2, p. 173-177, 2002.

Gomez, K. A.; Gomez, A. A. Statistical procedures for agricultural research. 2. ed. New York: John Wiley and Sons, 1984.

Houngnon, P.; Assevedo, A.; Bernard, M. Extrait de Promenade Botanique. In Yesso'e (Clerodendrum capitates). 1990. Available from:

$<$ http://www.runetwork.de/html/en/index.html? articleid=525>. Accessed in: Oct. 22, 2015.

Idris, G. L.; Omojowo, F. S. Comparative study of ground nut oil and sodium chloride as protectants against insect infestation of smoked dried fish in Kainji Lake areas. Journal of Fish and Aquaculture Science, v. 8, n. 1, p. 238242, 2013. Available from: $<$ http://scialert.net/qredirect.php?doi=jfas.2013. 238.242\&linkid $=$ pdf $>$. Accessed in: Oct. 22, 2015. 
Jose, A. R.; Adesina, J. M. Larval susceptibility of Dermestes maculatus (Degeer, 1776) (Coleoptera: Dermestidae) to Secamone afzelii (Schult) K. Schum leaf powder on smoke-dried fish. International Journal of Aquaculture, v. 4, n. 17, p. 102-107, 2014. Available from: $<$ http://biopublisher.ca/index.php/ija/article/vie w/1297/1224>. Accessed in: Oct. 22, 2015.

Juvekar, A. R.; Nachankar, R. S.; Hole, R. C.; Wakade, A. S.; Kulkarni, M. P.; Ambaye, R. Y. In vitro and in vivo immunomodulatory activity of aqueous extract of Clerodendrum serratum L. roots. Planta Medica, v. 72, p. 1009, 2006.

Kedia, A.; Prakash, B.; Mishra, P. K.; Singh, P.; Dubey, N. K. Botanicals as eco friendly biorational alternatives of synthetic pesticides against Callosobruchus spp. (Coleopetra: Bruchidae): a review. Journal of Food Science and Technology, v. 52, n. 3, p. 1239-1257, $2015 . \quad$ Available from: <http://link.springer.com/article/10.1007/s1319 7-013-1167-8\#/page-1>.

Kemabonta, K. A.; Falodu, B. B. Bioefficacy of three plant products as post-harvest grain protectants against Sitophilus oryzae Linnaeus (Coleoptera: Curculionidae) on stored wheat (Triticum aestivum). International Journal of Science and Nature, v. 4, n. 2, p. 259-264, 2013.

Nayak, M. K.; Collins, P. J.; Throne, J. E.; Wang, J. J. Biology and management of psocids infesting stored products. Annual Review of Entomology, v. 59, p. 279-297, 2014.

Obiakor, M. O.; Ezeonyejiaku, C. D.; Ezenwelu, C. O. Biotoxicity and eco-friendly characterization of plant materials as green pesticides for the control of fish beetles
(Demestes maculatus). Journal Life Science and Biomedicine, v. 3, n. 4, p. 300-307, 2013.

Okonkwo, E. O.; Okoye, W. I. Insecticidal activity of Dennettia tripetal Baker and Piper guineense Schum and Thonn against Dermestes maculatus Degeer (Coleptera: Dertidae) and Necrobia rufupes Degeer (Coleoptera: Cleridae) on dried fish. Nigeria Journal of Entomology, v. 18, p. 109-117, 2001.

Osuji, F. N. C. The development of Necrobia rufipes in dried fish and certain other commodities. Nigeria Journal of Science, v. 15, p. 21-32, 1975.

Rajashekar, Y.; Ravindra, K. V.; Bakthavatsalam, N. Leaves of Lantana camara Linn. (Verbenaceae) as a potential insecticide for the management of three species of stored grain insect pests. Journal of Food Science and Technology, v. 51, n. 11, p. 3494-3499, 2014.

Sharma, D. K.; Bhuyan, S. K. Hypolipidemic effect of Clerodendrum colebrookianum Walp glycosides in C3H mice. Planta Medica, v. 72, p. 1041, 2006.

Tapondju, L. A.; Alder, A.; Bonda, H.; Fontem, D. A. Efficacy of powder and oil from Chenpodium brosioides leaves as post-harvest grain protectants against six stored products beetles. Journal of Stored Products Research, v. 38, p. 395-402, 2002.

Weaver, D. K.; Subramanyam, B. Botanicals. In: Subramanyam, B. H.; Hagstrum, D. W. (Eds.). Alternatives to pesticides in storedproduct IPM. Dordrecht: Kluwer Academic Publishers, 2000. p. 303-320.

Woo, P. T. K. Immunological responses of fish to parasitic organisms. Annual Review of Fish Disease, v. 2, p. 339-366, 1992.

License information: This is an open-access article distributed under the terms of the Creative Commons Attribution License, which permits unrestricted use, distribution, and reproduction in any medium, provided the original work is properly cited. 